Journal of Extension Education

Vol. 28 No. 2, 2016

\title{
Technology Utilization of Banana in Thiruvananthapuram District of Kerala
}

\author{
S. Thasneem ${ }^{1}$ and B. Seema ${ }^{2}$
}

\begin{abstract}
The present study conducted in Thiruvananthapuram district of Kerala involved 90 commercial banana growers, The objective of the study was to assess the level of adoption of selected KAU (Kerala Agricultural University) practices in banana cultivation $A$ wellstructured interview schedule was used for data collection from the respondents. The study revealed that majority of the farmer respondents had medium level of adoption.
\end{abstract}

Keywords : Banana, farmer, level of adoption, Kerala

\section{INTRODUCTION}

Banana is the second important fruit crop in in India. It is being cultivated in climates ranging from humid tropical to dry mild subtropical. Thirty-three percent of the world's banana is produced in India. It is an important fruit crop in the state of Kerala too. India leads the world in banana production with an annual output of about 14.2 million tonnes / year. The fruit ranks first in production and third in area among fruit crops. It accounts for 13 per cent of the total area and 33 per cent of the production of fruits. In 1985-86, the area under banana cultivation was 16500 ha and in 2004-05 the area had increased to 59000ha. On the otherhand, productivity of banana had decreased from 13816 $\mathrm{kg} / \mathrm{ha}$ in $1995-96$ to $8075 \mathrm{~kg} / \mathrm{ha}$ in 2004-05.
For greater improvement in banana cultivation Kerala Agricultural University (KAU) and research institutions have developed many innovative technologies. KAU has evolved and standardized many technologies such as selection and curing of suckers, planting and spacing, manurial practices, sulphate of potash bunch covering, inter-cropping, tissue culture, double sucker etc. The success of a technology depends on how far it is adopted by the people and how it continues to provide welfare to the social system. Because of the crop specific complexity of agricultural technology, different institutional arrangements are needed to transfer different types of technologies to technology users. For profitable cultivation of banana, it becomes essential for the farmers to choose the

1-PG Scholar and 2- Professor, Department of Agricultural Extension, College of Agriculture, Kerala Agricultural University, Vellayani-695522, Thiruvananthapuram, Kerala 
appropriate technology released by the research system. Hence an attempt was made to assess the adoption of selected KAU practices on banana cultivation by commercial banana growers.

\section{METHODOLOGY}

The study was conducted in Thiruvananthapuram district of Kerala involving 90 commercial banana growers. From the eleven blocks of Thiruvananthapuram district, three blocks having maximum area under banana cultivation were selected based on secondary data and in consultation with agricultural department officials. From each block, one panchayat was selected which is having maximum area under banana cultivation. From each panchayat 30 commercial banana growers were selected with a holding size not less than 0.5 ha each using simple random sampling. Thus a total of 90 commercial banana grower respondents were selected for the study. From the package of practice recommendation of KAU for banana, nineteen practices were selected based on judges rating of which ten were production practices, four plant protection practices and five tissue culture cultivation practices. A wellstructured interview schedule was used for data collection from the respondents to measure the adoption of selected KAU practices. The results were analysed with the help of different statistical tools like mean, frequency, percentage and standard deviation.

\section{FINDINGS AND DISCUSSION}

The findings of the study are being presented hereunder.

\section{Adoption of Production Practices}

Values in Table 1 reveal the comparison of awareness and adoption of each production practices. Wide variation in awareness and adoption was found in selection of sword suckers and paring and pralinage. More than 85 per cent of respondents were aware about these two practices. But only 66.7 per cent of respondents actually adopted in the field. Farmers were making use of ready made planting material from market for cultivation. So they were not actually selecting sword suckers or practicing paring and pralinage directly. About 71.1 per cent of farmers were aware about method of planting in pits, but only 61.1 per cent had actually adopted in the field because majority opined that easy bud initiation is possible when suckers are planted in pits with more tilt. About 44 per cent had of respondents were aware about spacing, but only 35.6 per cent adopted it. This is because they got higher yield while practicing lesser spacing. They could accommodate more number plants in lesser spacing. Similar finding was reported by Bennur (2011).

When it comes to awareness about fertilizer recommendation, 38.9 per cent were aware about it but only 30 per cent had adopted in the field. The decrease in percentage of adoption might be because 
Table 1.

Distribution of Respondents According to Adoption of Production Practices

$\mathrm{n}=90$

\begin{tabular}{|c|c|c|c|c|c|}
\hline \multirow{2}{*}{$\begin{array}{l}\text { S1. } \\
\text { No. }\end{array}$} & \multirow{2}{*}{ Practices } & \multicolumn{2}{|c|}{ Awareness } & \multicolumn{2}{|c|}{ Adoption } \\
\hline & & $\mathbf{F}$ & $\mathbf{P}$ & $\mathbf{F}$ & $\mathbf{P}$ \\
\hline 1 & $\begin{array}{l}\text { Selection of } 3-4 \text { month old disease } \\
\text { free sword suckers. }\end{array}$ & 77 & $85.6 \%$ & 60 & $66.7 \%$ \\
\hline 2 & $\begin{array}{l}\text { Treatment of suckers : smeared with } \\
\text { cowdung solution and ash and dried } \\
\text { in sun for about 3-4 days. }\end{array}$ & 79 & $87.8 \%$ & 60 & $66.7 \%$ \\
\hline 3 & $\begin{array}{l}\text { Plant suckers upright in the centre of } \\
\text { pits with } 5 \mathrm{~cm} \text { pseudostem remaining } \\
\text { above soil level. }\end{array}$ & 64 & $71.1 \%$ & 55 & $61.1 \%$ \\
\hline 4 & Spacing $2 \mathrm{~m} \times 2 \mathrm{~m}$. & 40 & $44.4 \%$ & 32 & $35.6 \%$ \\
\hline 5 & $\begin{array}{l}\text { Fertilizer recommendation } \\
\text { 190:115:300. }\end{array}$ & 35 & $38.9 \%$ & 27 & $30 \%$ \\
\hline 6 & $\begin{array}{l}\text { Intercropping with Cucumber and } \\
\text { Amaranthus. }\end{array}$ & 70 & $77.8 \%$ & 68 & $75.6 \%$ \\
\hline 7 & Propping & 80 & $88.9 \%$ & 75 & $83.3 \%$ \\
\hline 8 & Pre harvest bunch sprays of $3 \% \mathrm{~K}_{2} \mathrm{SO}_{4}$. & 5 & $5.5 \%$ & 5 & $5.5 \%$ \\
\hline 9 & Bunch covering & 70 & $77.8 \%$ & 67 & $74.4 \%$ \\
\hline 10 & Irrigation & 80 & $88.9 \%$ & 80 & $88.9 \%$ \\
\hline
\end{tabular}

F - Frequency, P- Percentage

most of them use organic fertilizers in the field instead of chemical fertilizers. It also indicates the need for creation of awareness among farmers about chemical fertilizer application. Intercropping with cucumber and amaranthus was done by 75.6 per cent farmers but 77.8 per cent had awareness about this practice. Propping is a method of giving support to banana plant to overcome lodging by wind and 88.9 per cent farmers were aware about propping and 83.3 per cent farmers adopted propping. But most of the farmers can't afford the price of the support used in popping. Bunch covering is practiced by 74.4 per cent farmers and 77.8 per cent were aware about the method. In the case of pre harvest bunch spraying with 3 per cent $\mathrm{K}_{2} \mathrm{SO}_{4}$,only 5.5 per cent of the farmers were aware aboutthis which points to the need for creation of awareness about this practice among farmers. However, in this case as well as in the case of irrigation those who 
Table 2.

Distribution of Respondents According to Adoption of Plant Protection Practices

$\mathrm{n}=90$

\begin{tabular}{|c|l|c|c|c|c|}
\hline S1. & \multicolumn{1}{|c|}{ Practices } & \multicolumn{1}{|c|}{ Awareness } & \multicolumn{2}{|c|}{ Adoption } \\
\cline { 3 - 6 } No. & \multicolumn{1}{|c|}{ F } & P & F & P \\
\hline 1 & $\begin{array}{l}\text { Spray 1\% Bordeaux mixture soon } \\
\text { after the appearance of the initial } \\
\text { symptoms of the leaf spot. }\end{array}$ & 45 & $50 \%$ & 38 & $42.2 \%$ \\
\hline 2 & $\begin{array}{l}\text { Set traps using pseudostem of } \\
\text { approximately 0.5m length, which are } \\
\text { split length - wise and laid in the field } \\
\text { for controlling rhizome weevil. }\end{array}$ & 30 & $33.3 \%$ & 23 & $25.5 \%$ \\
\hline 3 & $\begin{array}{l}\text { Apply quinalphos 0.05\% or } \\
\text { chlorpyrifos 0.03\% for controlling } \\
\text { pseudo stem weevil. }\end{array}$ & $38.1 \%$ & 21 & $23.3 \%$ \\
\hline 4 & $\begin{array}{l}\text { Use disease - free planting material for } \\
\text { controlling viral diseases like banana } \\
\text { bunchy top }\end{array}$ & 70 & $77.7 \%$ & 60 & $66.6 \%$ \\
\hline
\end{tabular}

F - Frequency, P- Percentage

were aware were found to be adopting it too.

\section{Adoption of Plant Protection Practices}

From the table, we can interpret that 50 per cent of respondents were aware about the chemical control of leaf spot but only 42.2 per cent adopted this practice. The percentage of farmers who were aware about pseudo stem trap for controlling rhizome weevil was 33.3 per cent and 25.5 per cent had adopted this method. The low awareness about trap for checking pseudostem weevil points to the need for creating awareness about it among farmers. Control of pseudo stem weevil is being done by 23.3 per cent but 31.1 per cent were aware. Nearly 78 per cent of respondents were aware about the control of diseases like banana bunchy top and 66.6 per cent were controlling it by using disease free planting material.

Here we can observe that there is a wide gap between awareness and adoption because most of the farmers opine that chemical control of pests and diseases are not sustainable. Hence, most of the farmers go for traditional chemical - free methods. 
The finding derives support from studies reported by Benner (2011) and Sujitha (2015).

\section{Adoption of Tissue Culture Banana Cultivation}

About 61.5 per cent of farmers were aware about spacing of tissue culture banana but only 38.46 per cent had practiced this method. They obtain good yield when practicing lesser spacing. Pit size recommended was $50 \mathrm{~cm}^{3}$ and only 38.5 per cent farmers were aware about the pit size and 23.07 per cent of them adopted this pit size. About 46.15 per cent of them were aware about the

Table 3.

Distribution of Respondents According to Adoption of Tissue Culture Banana Cultivation

$$
\mathrm{n}=13
$$

\begin{tabular}{|c|l|l|l|l|c|}
\hline \multirow{2}{*}{$\begin{array}{c}\text { S1. } \\
\text { No. }\end{array}$} & \multicolumn{1}{|c|}{ Practices } & \multicolumn{1}{|c|}{ Awareness } & \multicolumn{2}{c|}{ Adoption } \\
\cline { 3 - 6 } & \multicolumn{1}{|c|}{ F } & \multicolumn{1}{|c|}{ P } & F & P \\
\hline 1 & Spacing 2m X 2m. & 8 & $61.5 \%$ & 5 & $38.50 \%$ \\
\hline 2 & Pit size 50 cm X 50cm X 50cm. & 5 & $38.5 \%$ & 3 & $23.07 \%$ \\
\hline 3 & $\begin{array}{l}\text { Double sucker planting at a spacing of } \\
\text { 3mX2m. }\end{array}$ & 6 & $46.15 \%$ & 3 & $23.07 \%$ \\
\hline 4 & $\begin{array}{l}\text { Fill the pits with top soil and FYM 15-20 } \\
\text { Kg per plant per pit. }\end{array}$ & 7 & $53.9 \%$ & 6 & $46.15 \%$ \\
\hline 5 & $\begin{array}{l}\text { High density planting with 1.75mX1.75m } \\
\text { with one plant per pit. }\end{array}$ & 3 & $23.07 \%$ & 3 & $23.07 \%$ \\
\hline
\end{tabular}

F - Frequency, P- Percentage

double sucker planting but only 23.07 per cent adopted it. Only 23.07 per cent of farmers had awareness about high density planting and, adopting it too. Hence more efforts should be made to create awareness among farmers about advantages and correct recommendations to be followed in cultivating tissue culture banana.

From the study of adoption of KAU practices on banana cultivation it could be observed that majority of them (73.3\%) had medium level of adoption. Moreover 14.4 per cent of them had low level followed by 12.2 per cent with high level of adoption.

Perusal of Table 4 reveals that there were 1.1 per cent innovators, 13.3 per cent early adopters, 35.5 per cent early majority, 34.4 per cent late majority and 15.5 per cent laggards among the respondents. There is slight variation from standard Roger's curve of adoption. As per standard Roger's curve, 2.5 per cent innovators and 34 per cent of early majority will be there normally. In this study, only 1.1 per cent innovators and 35.5 per cent early majority were 
Table 4.

Distribution of Respondents Based on Adopter Categories

\begin{tabular}{|c|l|c|c|}
\hline \multicolumn{1}{|c|}{ Category } & Frequency & Percentage \\
\hline 1 & Innovators & 1 & $1.10 \%$ \\
\hline 2 & Early adopters & 12 & $13.30 \%$ \\
\hline 3 & Early majority & 32 & $35.50 \%$ \\
\hline 4 & Late majority & 31 & $34.40 \%$ \\
\hline 5 & Laggards & 15 & $15.50 \%$ \\
\hline
\end{tabular}

present, which could be attributed to the poor faith of banana growers on the new technologies. The scientists and the extension personnel in the state should take a cue from this and strengthen the research and extension system in banana farming.

\section{CONCLUSION}

From the study of adoption of KAU practices on banana cultivation it could be observed that majority of them had medium level of adoption.

Though more than 85 percent of respondents were aware about selection of sword suckers and paring $\&$ prolinage, they were not directly adopting it. In the case of preharvest bunch spray with 3 percent $\mathrm{K}_{2} \mathrm{SO}_{4}$, awareness was only negligible. Also awareness about correct spacing, fertilizer recommendation, spraying one per cent Bordeaux mixture for controlling leafspot, use of traps in rhizome weevil, chemical control of pseudostem weevil and high density planting were poor. Hence efforts should be taken to create awareness about these practices among banana growers, there by increasing the adoption level.

\section{REFERENCES}

Bennur (2011). Adoption of banana farming practices and constraints of growers in Gulbarga district of Karnataka, International Journal of Farm Sciences 5(1) : 210-213, 2015

Sujitha, P. S. (2015). Technology assessment of plant protection practices of economically dominant crops in homegardens. Unpublished M. Sc. (Ag.) thesis, Kerala Agricultural University, Vellanikkara 